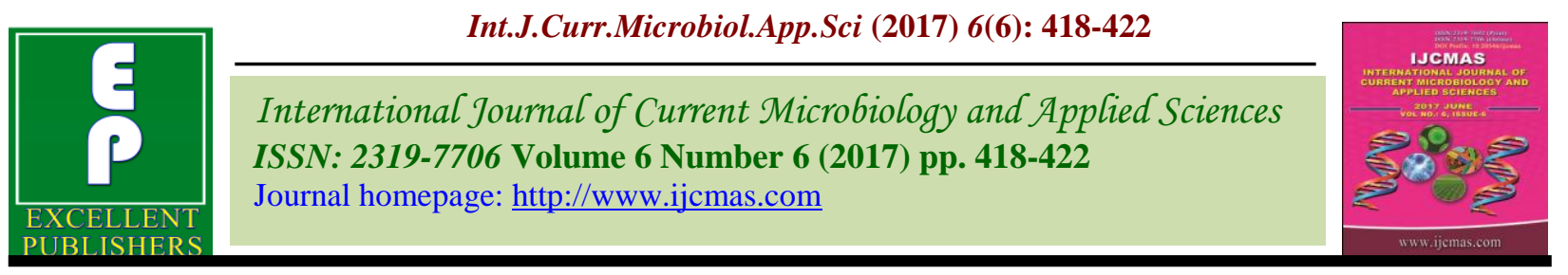

Original Research Article https://doi.org/10.20546/ijcmas.2017.606.049

\title{
Correlation Coefficient and Path Analysis in Coriander (Coriandrum sativum L.) Genotypes
}

\author{
Harishchand Ram ${ }^{1}$, Mohd. Meraj Khan ${ }^{1 *}$, V.P. Pandey ${ }^{1}$ and D.K. Dwivedi ${ }^{2}$ \\ ${ }^{1}$ Department of Vegetable Science, Narendra Deva University of Agriculture and Technology, \\ Kumarganj, Faizabad (U.P.), India \\ ${ }^{2}$ Department of Genetics and Plant Breeding, Narendra Deva University of Agriculture and \\ Technology, Kumarganj, Faizabad (U.P.), India \\ *Corresponding author
}

A B S T R A C T

The field experiment was carried out during Rabi season of the year 2010-2011 at Main Experiment Station (Vegetable Research Farm), Narendra Deva University

Keywords

Coriander,

Correlation coefficient,

Path analysis and yield.

Article Info

Accepted: 04 May 2017 Available Online: 10 June 2017 of Agriculture and Technology, (Narendra Nagar) Kumarganj, Faizabad (U.P.) India. 110 lines of coriander germplasm maintained in All India Co-ordinated research project on spices under Department of Vegetable Science NDUAT, Kumarganj, Faizabad were taken for this investigation. This study revealed that the seed yield per plot showed highly and positive significant correlation with test weight (0.6008) followed by seed yield per plant (0.5995). The highest positive direct effect on seed yield per plant (g) was exhibited by test weight $(0.3225)$ followed by secondary branches per plant (0.2292) and umbellets per umbel (0.1087). The perusal of path coefficient analysis shown that the highest positive direct effect on seed yield per plant $(\mathrm{g})$ was exhibited by test weight $(0.3225)$ followed by secondary branches per plant (0.2292) and umbellets per umbel (0.1087). Therefore, greater emphasis should be given on these characters while selecting for higher yield and related traits.

\section{Introduction}

Coriander is one of the important spices crop grown throughout the world. It is a native of Mediterranean region. It is grown for both green leaves and dried seeds. In the country it is grown on an about 543 thousand hectares area with 524 million tonnes production and 1.0 million tonnes per hectare productivity and in Uttar Pradesh it is grown on an about 6.68 thousand hectares area with 3.61 million tones production and 2.6 tonnes per hectare productivity (Anonymous, NHB, 2013-14). It is extensively grown in Andhra Pradesh, Tamil Nadu, Karnataka, Punjab, Rajasthan, Madhya Pradesh and Uttar Pradesh. Rajasthan is the major growing state and contributes about 40 per cent of coriander production in India. Coriander is an important spices and annual herb, which is botanically known as Coriandrum sativum L. and belong to the family Apiaceae. Coriander leaves is used for preparing chutneys, sauces and for curries and soups. The seeds are extensively used as 
condiments and medicine. The coriander oil is used as valuable ingredient in perfumes and food industries. The coriander seeds are used as spices in the preparation of curry powder and pickling spice. They are used for flavouring pastry, cookies-cakes, tobacco, bakery product, meat fish, soda, syrups, candy, preserve and liquour. Correlation and path analysis will establishes the extent of association between yield and its component and also bring out the relative importance of their direct and indirect effects and thus, gives a clear understanding of their association with yield. Keeping this in view, the present investigation was done to know the association among characters and path analysis in coriander.

\section{Materials and Methods}

The present investigation was conducted at Main Experiment Station (Vegetable Research Farm), Narendra Deva University of Agriculture and Technology, (Narendra Nagar) Kumarganj, Faizabad (U.P.) India, during Rabi season of 2010-11. 110 lines of coriander germplasm maintained in All India Co-ordinated research project on spices under Department of Vegetable Science NDUAT, Kumarganj, Faizabad were taken for this investigation. These genotypes were collected from different places of India.

The experiment was conducted in Augmented Block Design. Seed were sown in line by maintaining $40 \times 20 \mathrm{~cm}$ plant spacing during first week of November. All the recommended cultural practices were followed to raise good crop. The observations were recorded on five selected plants of each row. The simple correlations between different characters were estimated according to Searle (1961) and path coefficient analysis was carried out according to Dewey and $\mathrm{Lu}$ (1959).

\section{Results and Discussion}

Yield of a crop is the result of interaction of a number of inter-related characters. Therefore, selection should be done based on these component characters after assessing their correlation with the yield. Character association revealed that mutual relationship between two characters and it is important for taking a decision regarding the nature of selection to be followed for improvement in the crop under study. The correlation among the yield and yield components in coriander are presented in table 1 . The coefficient of correlation in general was high in magnitude indicating a strong inherent association among various characters.

The seed yield per plot showed highly and positive significant correlation with test weight (0.6008) followed by seed yield per plant (0.5995). Therefore, these characters should be considered while making selection for yield improvement in coriander. The days to maturity show highly and positive significant correlation with days to $50 \%$ flowering (0.7887). The secondary branches per plant showed high and positively significant association with primary branches (0.6425), followed by plant height (0.3393). These findings are in line with Meena et al., (2014) and Sanker and Khader (1991).

Test weight showed positive correlation with seed yield per plant (0.3936). Similar results were also reported by Sanjeev et al., (1990). Yield is the sum total of the several component characters which directly or indirectly contributed to it. The information derived from the correlation studies indicated only mutual association among the characters. Whereas, path coefficient analysis helps in understanding the magnitude of direct and indirect contribution of each character on the dependent characters like seed yield. 
Table.1 Estimates of simple correlation coefficient among different characters in coriander

\begin{tabular}{|c|c|c|c|c|c|c|c|c|c|c|c|c|}
\hline S. No. & Character & $\begin{array}{c}\text { Days to } \\
50 \% \\
\text { flowering }\end{array}$ & $\begin{array}{c}\text { Plant } \\
\text { height } \\
(\mathrm{cm})\end{array}$ & $\begin{array}{c}\text { Primary } \\
\text { branches/ } \\
\text { Plant }\end{array}$ & $\begin{array}{c}\text { Secondary } \\
\text { branches/ } \\
\text { plant }\end{array}$ & $\begin{array}{l}\text { Days to } \\
\text { maturity }\end{array}$ & $\begin{array}{c}\text { Umbels/ } \\
\text { plant }\end{array}$ & $\begin{array}{c}\text { Umbellets/ } \\
\text { umbel }\end{array}$ & $\begin{array}{l}\text { Seeds/ } \\
\text { umbel }\end{array}$ & $\begin{array}{c}\text { Test } \\
\text { weight } \\
\text { (g) }\end{array}$ & $\begin{array}{c}\text { Seed } \\
\text { yield/ } \\
\text { plant }(g)\end{array}$ & $\begin{array}{c}\text { Seed } \\
\text { yield/ plot } \\
(\mathrm{Kg})\end{array}$ \\
\hline 1 & Days to $50 \%$ flowering & 1.0000 & 0.0202 & -0.0368 & -0.0272 & $0.7887 * *$ & -0.0405 & -0.0942 & 0.0973 & 0.0714 & -0.0510 & -0.0010 \\
\hline 2 & Plant height (cm) & & 1.0000 & 0.2932 & 0.3393 & 0.0349 & 0.1454 & 0.2441 & $\begin{array}{c}- \\
0.0614\end{array}$ & 0.0938 & 0.1379 & 0.0062 \\
\hline 3 & Primary branches/ plant & & & 1.0000 & $0.6425 * *$ & -0.0179 & 0.1890 & 0.2796 & 0.1759 & 0.0886 & 0.0976 & 0.0004 \\
\hline 4 & Secondary branches/ plant & & & & 1.0000 & -0.0115 & 0.1547 & 0.2966 & 0.1264 & 0.1118 & 0.2371 & 0.1625 \\
\hline 5 & Days to maturity & & & & & 1.0000 & -0.0555 & -0.0435 & 0.0676 & 0.0396 & -0.0271 & 0.0167 \\
\hline 6 & Umbels/ plant & & & & & & 1.0000 & 0.2591 & 0.0720 & 0.3003 & 0.1447 & 0.1288 \\
\hline 7 & Umbellets/ umbel & & & & & & & 1.0000 & 0.0695 & 0.2853 & 0.2549 & 0.3194 \\
\hline 8 & Seeds/ umbel & & & & & & & & 1.0000 & 0.3134 & 0.1962 & 0.2727 \\
\hline 9 & Test weight (g) & & & & & & & & & 1.0000 & 0.3936 & $0.6008 * *$ \\
\hline 10 & Seed yield/ plant (g) & & & & & & & & & & 1.0000 & $0.5995 * *$ \\
\hline 11 & Seed yield/plot $(\mathbf{K g})$ & & & & & & & & & & & 1.0000 \\
\hline
\end{tabular}


Table.2 Direct and indirect effect of different characters on seed yield of coriander

\begin{tabular}{|c|c|c|c|c|c|c|c|c|c|c|c|}
\hline S. No. & Character & $\begin{array}{c}\text { Days to } \\
50 \% \\
\text { flowering }\end{array}$ & $\begin{array}{c}\text { Plant } \\
\text { height } \\
(\mathrm{cm})\end{array}$ & $\begin{array}{c}\text { Primary } \\
\text { branches/ } \\
\text { plant }\end{array}$ & $\begin{array}{c}\text { Secondary } \\
\text { branches/ } \\
\text { plant }\end{array}$ & $\begin{array}{l}\text { Days to } \\
\text { maturity }\end{array}$ & $\begin{array}{l}\text { Umbels/ } \\
\text { plant }\end{array}$ & $\begin{array}{l}\text { Umbellets/ } \\
\text { umbel }\end{array}$ & $\begin{array}{l}\text { Seeds/ } \\
\text { umbel }\end{array}$ & $\begin{array}{c}\text { Test } \\
\text { weight }(\mathrm{g})\end{array}$ & $\begin{array}{c}\text { Seeds } \\
\text { yield/ } \\
\text { plant (g) }\end{array}$ \\
\hline 1 & $\begin{array}{l}\text { Days to 50\% } \\
\text { flowering }\end{array}$ & -0.1029 & -0.0021 & 0.0038 & 0.0028 & -0.0812 & 0.0042 & 0.0097 & -0.0100 & -0.0073 & -0.0510 \\
\hline 2 & Plant height (cm) & 0.0011 & 0.0525 & 0.0154 & 0.0178 & 0.0018 & 0.0076 & 0.0128 & -0.0032 & 0.0049 & 0.1379 \\
\hline 3 & $\begin{array}{l}\text { Primary branches/ } \\
\text { plant }\end{array}$ & 0.0053 & -0.0419 & -0.1428 & -0.0917 & 0.0026 & -0.0270 & -0.0399 & -0.0251 & -0.0127 & 0.0976 \\
\hline 5 & Days to maturity & 0.0296 & 0.0013 & -0.0007 & -0.0004 & 0.0376 & -0.0021 & -0.0016 & 0.0025 & 0.0015 & -0.0271 \\
\hline 6 & Umbels/ plant & 0.0002 & -0.0008 & -0.0010 & -0.0008 & 0.0003 & -0.0053 & -0.0014 & -0.0004 & -0.0016 & 0.1447 \\
\hline 7 & Umbellets/ umbel & -0.0102 & 0.0265 & 0.0304 & 0.0322 & -0.0047 & 0.0282 & 0.1087 & 0.0076 & 0.0310 & 0.2549 \\
\hline 8 & Seeds/ umbel & 0.0092 & -0.0058 & 0.0167 & 0.0120 & 0.0064 & 0.0068 & 0.0066 & 0.0948 & 0.0297 & 0.1962 \\
\hline 9 & Test weight (g) & 0.0230 & 0.0303 & 0.0286 & 0.0360 & 0.0128 & 0.0968 & 0.0920 & 0.1011 & 0.3225 & 0.3936 \\
\hline
\end{tabular}

RESIDUAL EFFECT $=0.8807$ diagonal values are direct effects; above and below diagonal are indirect effects. 
Partitioning of correlation coefficient into direct and indirect effects provide information about the nature and magnitude of effects of other characters on seed yield. The result of the present investigation on path coefficient analysis as presented in table 2 revealed that the highest positive direct effect on seed yield per plant (g) was exhibited by test weight $(0.3225)$ followed by secondary branches per plant (0.2292) and umbellets per umbel (0.1087). These indicate that seed yield could be improved by making selection on the basis these characters. These findings are in agreement with Datta et al., (2006), Kumar (1997), Vedamuthu et al., (1989), Choudhary (1987), Jain et al., (2003), Srivastava et al., (2000) and Srivastava et al., (2000).

Path coefficient analysis indicated that utility of the character like test weight $(\mathrm{g})$ which showed highest positive direct effects on seed yield per plant. These are major yield contributing traits for enhancing the yield of coriander. From the above study it is concluded that test weight, secondary branches per plant and umbellets per umbel should be given more emphasis in the selection aimed at improving seed yield per plant in coriander.

\section{References}

Anonymous 2014-15. National Horticulture Board, data base.

Choudhary, C.L. 1987. Association of developmental characters with grain yield in coriander (Coriander sativum L.). M.Sc. (Ag.) Thesis, Sukhadia University, Udaipure, Campus-Jobner.

Datta, S., Chatterjee R. and Satya 2006. Correlation and path analysis studies on
Coriander (Coriandrum sativum L.). Horticulture Journal, 19: 65-67.

Dewey, D.R. and Lu, K.H. 1959. A correlation and path analysis of components of crusted wheat grass seed production. Agron. J., 5: 515-518.

Jain, U.K. and Singh, D. Amrita 2003. Correlation and path analysis for certain metric trails in coriander. Progressive Agriculture, 3(1): 86-88.

Kumar, S. 1997. Genetic Variability in coriander, M.Sc. (Ag.) Thesis, Deptt. Of Hort. (Veg. $\&$ Flori.), RAU, Pusa, Samastipur (Bihar).

Meena, R.S., Kakani, R.K., Chaudhary, S., Singh, B. and Panwar Alka 2014. Genetic diversity analysis in coriander (Coriandrum sativum) varieties. 3rd International Conference on Agriculture \& Horticulture held at Hyderabad International Convention Centre, India October, 27-29, 2014.

Sanjeev, A., Sharma, R.K. and Agrawal, S. 1990. Quality evaluation in coriander. Indian Cocoa arecanut and Spices Journal, 13(4): 137-138.

Sankar, K B. and Khader, M A. 1991. Studies on genetic Variability in coriander. South Indian Horticulture, 39: 312-14.

Searle, S.R. 1961. Phenotypic, genotypic and environmental correlations, Biometrics, 17: 474-480.

Srivastava, S.B.L., Tripathi, S. M. and Srivastava, J.P. 2000. Genetic divergene in coriander (Coriandrum sativum L.). Spices and Aromatic plant: Challenges and opportunities in the new century Contributory papers. Centennial Conference on spices and aromatic plant, Calicut, Kerala, India, 20-23 September, 2000. 68-70.

Vedamuthu, P.G.B., Khader, M.A. and Rajan, F.S. 1989. Yield components in coriander. South Indian Horticulture, 37 (5): 287-290.

\section{How to cite this article:}

Harishchand Ram, Mohd. Meraj Khan, V.P. Pandey and Dwivedi, D.K. 2017. Correlation Coefficient and Path Analysis in Coriander (Coriandrum sativum L.) Genotypes. Int.J.Curr.Microbiol.App.Sci. 6(6): 418-422. doi: https://doi.org/10.20546/ijcmas.2017.606.049 